\title{
MOLECULAR CHARACTERIZATION OF PENICILLIUM EXPANSUM ISOLATED FROM GRAPES AND ITS MANAGEMENT BY LEAF EXTRACT OF CHENOPODIUM MURALE
}

Iqra H. Khan, Arshad Javaid, Syeda F. Naqvi

Institute of Agricultural Sciences, University of the Punjab, Lahore, Pakistan.

ART ICLE I N F O

\section{Article History}

Received: January 19, 2021

Revised: March 11, 2021

Accepted: March 16, 2021

\section{Keywords}

Penicillium expansum

Chenopodium murale

Molecular identification

Blue mold

\begin{abstract}
A B S T R A C T
Penicillium expansum Link causes an economically important postharvest blue mold disease in a number of fruits and vegetables. In the present study, this fungus was isolated from rotted grapes and identified on morphological basis. Identification of the pathogen was further confirmed on molecular basis by using four different primer pairs namely ITS, $\beta$-tubulin, CMD and CF under accession numbers MN752155, MN787831, MN787832 and MN787833, respectively. Leaf extract of Chenopodium murale was assessed for its potential to control in vitro growth of $P$. expansum. For this purpose, leaves were extracted in methanol and after evaporation of the solvent, the resulting extract was successively partitioned with $n$-hexane, chloroform, ethyl acetate and $n$-butanol followed by antifungal bioassays with different concentrations (1.562 to $200 \mathrm{mg} \mathrm{mL}^{-1}$ ) of each organic solvent fraction. Although all the fractions controlled the fungal pathogen to variable extents, however, $n$-butanol fraction showed the highest antifungal activity causing $45-86 \%$ reduction in the biomass of $P$. expansum. Ethyl acetate fraction was also highly antifungal and reduced fungal biomass by $44-81 \%$. Chloroform and $n$-hexane fractions were comparatively less effective and reduced biomass of $P$. expansum by $30-72 \%$ and $11-44 \%$, respectively. This study concludes that ethyl acetate and $n$ butanol fractions are highly antifungal in nature against $P$. expansum.
\end{abstract}

Corresponding Author: Arshad Javaid

Email: arshad.iags@pu.edu.pk

(C) The Author(s) 2021.

\section{INTRODUCTION}

Grape (Vitis vinifera L.) is the first fruit berry that has a long history of cultivation by humans (Morata et al., 2017). It is cultivated on commercial basis in more than 75 countries with an average production of more than 23 million metric tons (FAOSTAT, 2020). It is a domesticated deciduous woody vine having numerous uses for producing table fruit, jelly, juice, wine, jam, vinegar, raisins and grape seed oil (Venkitasamy et al., 2019). It is considered as a non-climacteric type of fruit having green, red or black colors that grows well in a cluster of 20 to 270 (Migicovsky et al., 2017). It is enriched with essential nutrients such as minerals, vitamins, edible fibers, carbohydrates and phytochemicals. In grapes, polyphenols are considered as the most important phytochemicals because they possess many health-promoting benefits and biological activities (Cheng et al., 2020). In addition, grapes are a rich source of antioxidants such as flavones, anthocyanins, linalool, geranial, tannins and nerol (González-Barreiro et al., 2014). Due to its highly perishable nature, grape production is largely affected by a wide range of fungal pathogens (Kassemeyer, 2017). Among them, Penicillium is one of the most common groups of fungi that attacks on fresh table grapes during packaging and causes significant postharvest decay losses (Wang et al., 2019). In recent years, Penicillium expansum has become the main 
pathogen responsible for blue mold disease of grape in Pakistan. It represents a serious economic concern to the grape industry causing up to $60 \%$ of decay in stored fruit (Ghuffar et al., 2018). It produces several toxic compounds such as chaetoglobosins, citrinin and patulin that affect the quality of processed products (Tragni et al., 2021). P. expansum conidia typically penetrate through wounds and propagate on fruit surface even at below $0^{\circ} \mathrm{C}$ (He et al., 2019).

Although synthetic fungicides such as fluxapyroxad, cyprodinil and thiophanate methyl are used commonly for the control of postharvest losses by $P$. expansum, however, their application on large scale has compromised their efficacy by developing resistance in pathogen populations (Samaras et al., 2020). Public health concerns have stimulated the search for alternative control strategies for the effective management of $P$. expansum. In nature, plants are considered as a rich source of volatile compounds that are biologically active against fungal pathogens (Akhtar et al., 2020; Javaid et al., 2020; da Silva et al., 2020). Many studies have focused on $C$. murale for the effective control of phytopathogens (Naqvi et al., 2019; Naqvi et al., 2020). It belongs to family Chenopodiaceae. It is one of the fast-growing erect annual herbaceous weed natives to Europe (Farhan et al., 2019). Now, it is widespread to various parts of the world including Pakistan where it grows on different types of habitats. It grows abundantly in winter and early summer along the roadsides, cross walks, damp and waste places (Al-Batsh and Qasem, 2020). It is enriched with diterpenoids, terpenoids, flavonoids, glycosides, sterols, sesquiterpenes, glucosinolates, alkaloids, coumarins and phenolic acids with potent antifungal activities (Belmaghraoui et al., 2018). Therefore, the aim of this study was to identify $P$. expansum on molecular basis and to utilize the leaf extracts of $C$. murale for effective management of this pathogen of grapes.

\section{MATERIALS AND METHODS}

\section{Isolation and characterization of $P$. expansum}

Infected grapes with light brown spots were collected from Lahore, and surface sterilized in 3\% sodium hypochlorite solution for 1 min followed by washing with autoclaved water. The diseased area was carried out by using a needle and placed on freshly prepared malt extract agar. The inoculated plates were kept at $30{ }^{\circ} \mathrm{C}$ for five days. The obtained colonies were re-isolated to get pure cultures and studied on the basis of macroscopic and microscopic features at different magnifications under light microscope (Vico et al., 2014).

\section{Molecular identification using PCR}

The genomic DNA of the isolated fungus $P$. expansum was isolated by CTAB method following the protocol described by Doyle and Doyle (1990). The conventional PCRs were performed by using ITS, $\beta$-tubulin, CMD and CF primer pairs (Table 1). The obtained PCR products were analyzed by MiSeq Illumina sequencing, USA for bidirectional sequencing and then submitted to NCBI database for BLAST alignment search.

Table 1. List of oligonucleotide primers used for the characterization of P. expansum at molecular level.

\begin{tabular}{cllcc}
\hline No. & Primer name & \multicolumn{1}{c}{$5^{\prime}$ to 3' sequence } & Amplicon size (bp) & Annealing temperature \\
\hline 1 & ITS 1 Forward & TCCGTAGGTGAACCTGCGG & $\sim 638$ & \multirow{2}{*}{$60^{\circ} \mathrm{C}$} \\
2 & ITS 4 Reverse & TCCTCCGCTTATTGATATGC & & \\
3 & $\beta$-tubulin Forward & GGTAACCAAATCGGTGCTGCTTTC & $\sim 471$ & $62^{\circ} \mathrm{C}$ \\
4 & $\beta$-tubulin Reverse & ACCCTCAGTGTAGTGACCCTTGGC & & \\
5 & CMD 5 Forward & CCGAGTACAAGGARGCCTTC & $\sim 576$ & $65^{\circ} \mathrm{C}$ \\
6 & CMD 6 Reverse & CCGATRGAGGTCATRACGTGG & & \\
7 & CF 1 Forward & GCCGACTCTTTGACYGARGAR & & \\
8 & CF 4 Reverse & TTTYTGCATCATRAGYTGGAC & & \\
\hline
\end{tabular}

\section{Preparation of extracts}

Fresh C. murale plant leaves were collected from Punjab University, Lahore. The collected leaves were washed under running tap water, shade dried and grinded into a fine powder. The powdered leaves $(1 \mathrm{~kg})$ were dipped in methanol (5 L) for two weeks at room temperature and then passed through a filtration process by using two layers of filter paper. The obtained material was run-on a rotary evaporator to gain a thick gummy leaf extract. The crude extract was mixed in autoclaved water $(200$ 
$\mathrm{mL}$ ) and partitioned through a separating funnel with $n$ hexane $(4 \times 500 \mathrm{~mL})$, chloroform $(200 \mathrm{~mL})$, ethyl acetate $(200 \mathrm{~mL})$ and $n$-butanol $(100 \mathrm{~mL})$. The resultant solvents were run on rotary evaporator in order to get thick gummy material of each fraction (Banaras et al., 2020).

\section{Antifungal bioassays}

A mass of $1.2 \mathrm{~g}$ of each fraction of leaf extract was dissolved in DMSO $(1 \mathrm{~mL})$ followed by the addition of malt extract (ME) broth to raise the final volume up to 6 $\mathrm{mL}$ (stock solution) of $200 \mathrm{mg} \mathrm{mL}^{-1}$ concentration. The lower concentrations viz. 100, 50, 25, 12.5, 6.25 and $3.125 \mathrm{mg} \mathrm{mL}^{-1}$ were prepared by serial double dilution of the stock. A control set was also prepared without plant extract and each treatment was replicated thrice. Mature culture of $P$. expansum was used to prepare spore suspension and each glass tube was inoculated with $20 \mu \mathrm{L}$ of it and left to stand at $30^{\circ} \mathrm{C}$ for 7 days. After that, fungal mats were filtered on pre-weight filter papers, dried and weighed (Khan and Javaid, 2020).

\section{Statisłical analysis}

B

Data related to biomass of the P. expansum was analyzed by ANOVA and treatment means were separated by applying Tukey's HSD test at 5\% level of probability using software Statistix 8.1.

\section{RESULTS}

\section{Morphological identification of $P$. expansum}

Morphological features showed that the mature colonies of the fungus were circular and rapidly growing attaining a diameter of $5 \mathrm{~cm}$ at $30{ }^{\circ} \mathrm{C}$ in 7 days. The young colonies were off white in color, which upon maturity turned into light to dark green color whereas the reverse side of the plate was pale yellow to greenish in color (Figure 1). The observed conidia were 3.25 to $3.71 \times 2.56$ to $3.28 \mu \mathrm{m}$ in size, elliptical in shape, smooth surfaced having thin walls, attached with branched conidiophores. The germinated conidia form germ tubes. On the basis of morphological studies, the examined isolate was identified as P. expansum.
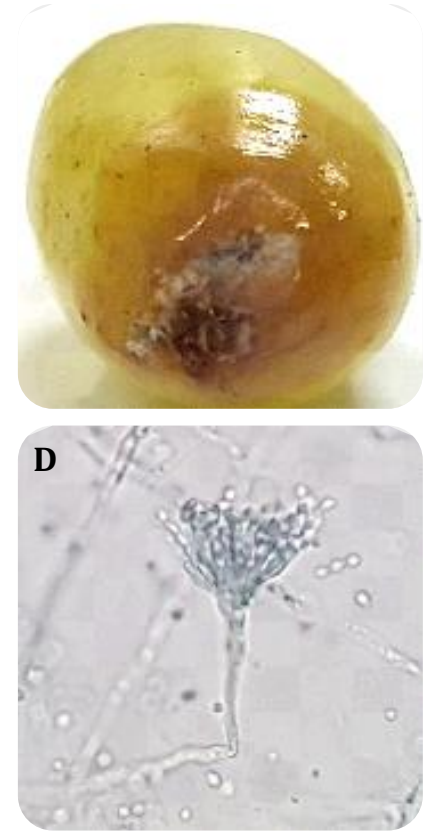
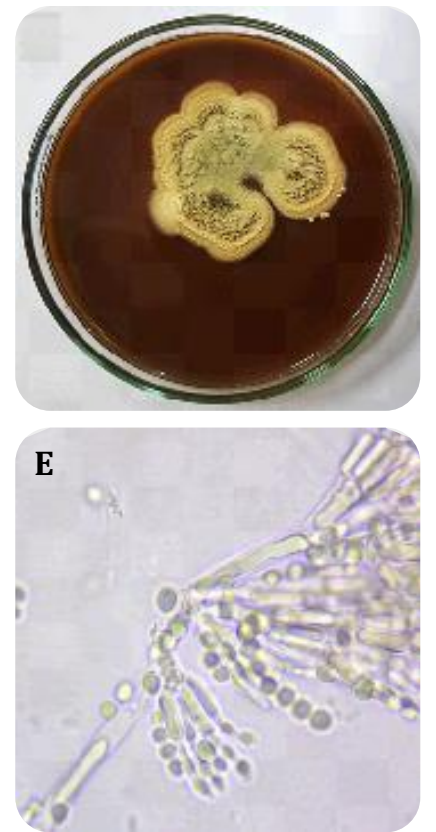
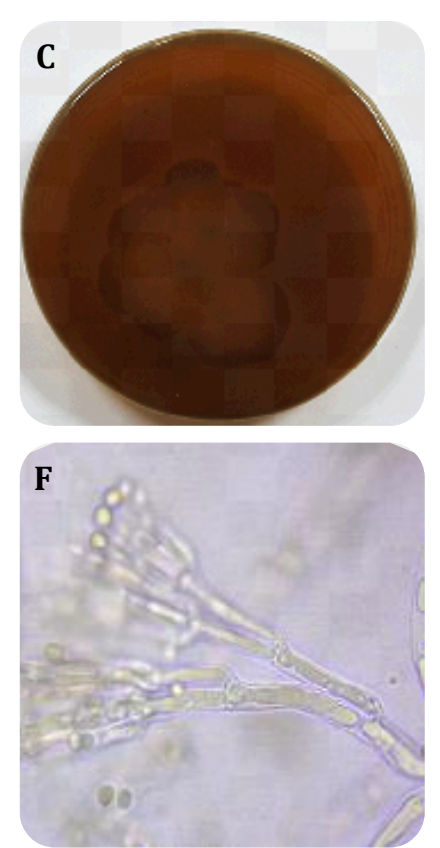

Figure 1. A)- Infected grape with Penicillium expansum (B)- Mature colony of P. expansum on MEA, (C)- Colony reverse on MEA, (D)- Conidia at 40X, (E \& F)- Conidia at 100X showing hyphae and conidiophores bearing conidia.

\section{Molecular characterization of $P$. expansum}

For more accuracy, molecular tools were used for the precise characterization of $P$. expansum as only microscopic studies are not sufficient due to huge similarities among the Penicillium species. Therefore, a total of four primer sets viz. ITS, $\beta$-tubulin, CMD and CF were used for the identification of P. expansum genomic DNA under MN752155, MN787831, MN787832 and MN787833 accession numbers, respectively with $99-100 \%$ similarities with already deposited specimens in the GenBank. As expected, the amplified PCR products generated specific bands of the appropriate sizes as shown in Figure 2. 


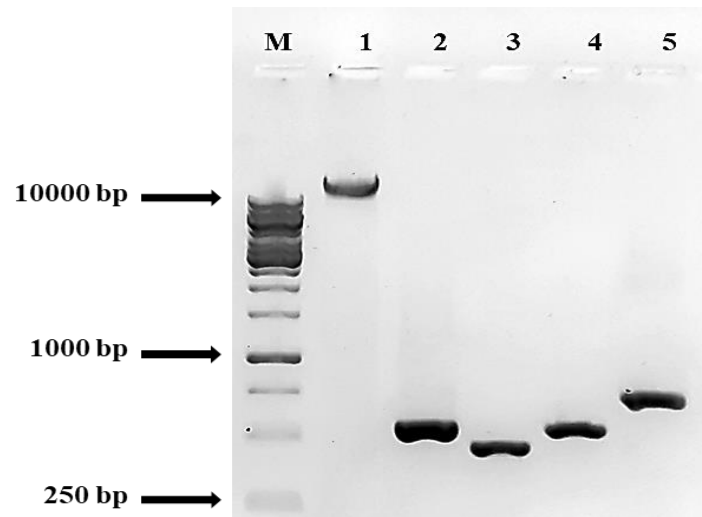

Figure 2. Agarose gel electrophoresis, (M): $1 \mathrm{~kb}$ DNA standard marker, (1): Genomic DNA of Penicillium expansum, (2): ITS1/ITS4 amplified PCR product, (3): $\beta$ tubulin amplified PCR product, (4): CMD5/CMD6 amplified PCR product, (5): CF1/CF4 amplified PCR product.

\section{Screening bioassays}

Four fractions of $C$. murale leaf extract were used against $P$. expansum that showed a significant suppressive effect on the growth of the targeted pathogen. Although all the fractions variably controlled the fungal pathogen, however, $n$-butanol fraction showed the highest antifungal activity causing $45-86 \%$ reduction in $P$. expansum biomass over control. Likewise, different concentrations of ethyl acetate fraction noticeably reduced the fungal biomass by $44-81 \%$. The other two fractions viz. chloroform and $n$-hexane were comparatively less effective and reduced biomass of $P$. expansum just by $30-72 \%$ and $11-44 \%$, respectively (Table 2).

Table 2. Effect of different concentrations of Chenopodium murale on growth of Penicillium expansum.

\begin{tabular}{ccccc}
\hline $\begin{array}{c}\text { Methanolic extract } \\
\text { fraction }\end{array}$ & $\begin{array}{c}\text { Conc. of DMSO } \\
\left(\mu \mathrm{mL}^{-1}\right)\end{array}$ & $\begin{array}{c}\text { Fraction conc. } \\
\left(\mathrm{mg} \mathrm{mL}^{-1}\right)\end{array}$ & Fungal biomass (mg) & $\begin{array}{c}\text { Decrease over } \\
\text { control (\%) }\end{array}$ \\
\hline Control & 1.29 & 0 & $60.2 \pm 4.3 \mathrm{ab}$ & - \\
& 2.59 & 0 & $60.5 \pm 2.3 \mathrm{a}$ & - \\
& 5.18 & 0 & $58.1 \pm 3.4 \mathrm{ab}$ & - \\
& 10.37 & 0 & $56.4 \pm 2.2 \mathrm{a}-\mathrm{c}$ & - \\
& 20.75 & 0 & $53.6 \pm 1.5 \mathrm{a}-\mathrm{d}$ & - \\
& 41.5 & 0 & $46.2 \pm 2.3 \mathrm{c}-\mathrm{e}$ & - \\
& 83 & 0 & $30.4 \pm 4.6 \mathrm{~g}-\mathrm{i}$ & - \\
\hline -Hexane & 166 & 0 & $29.2 \pm 1.6 \mathrm{~g}-\mathrm{j}$ & 11 \\
& 1.29 & 1.562 & $53.7 \pm 2.5 \mathrm{a}-\mathrm{d}$ & 19 \\
& 2.59 & 3.125 & $48.8 \pm 2.6 \mathrm{~b}-\mathrm{d}$ & 21 \\
& 5.18 & 6.25 & $46.0 \pm 1.0 \mathrm{c}-\mathrm{e}$ & 40 \\
& 10.37 & 12.5 & $34.1 \pm 2.3 \mathrm{f}-\mathrm{h}$ & 38 \\
& 20.75 & 25 & $33.4 \pm 2.6 \mathrm{f}-\mathrm{h}$ & 49 \\
& 41.5 & 50 & $23.5 \pm 1.1 \mathrm{~h}-\mathrm{m}$ & 30 \\
& 83 & 100 & $21.2 \pm 1.7 \mathrm{i}-\mathrm{h}$ & 44 \\
\hline Chloroform & 166 & 200 & $16.4 \pm 1.0 \mathrm{k}-\mathrm{o}$ & 30 \\
& 1.29 & 1.562 & $42.3 \pm 2.6 \mathrm{~d}-\mathrm{f}$ & 41 \\
& 2.59 & 3.125 & $35.7 \pm 1.4 \mathrm{e}-\mathrm{g}$ & 60 \\
& 5.18 & 6.25 & $23.3 \pm 2.1 \mathrm{~h}-\mathrm{m}$ & 54 \\
& 10.37 & 25 & $25.7 \pm 2.0 \mathrm{~g}-\mathrm{l}$ & 72 \\
& 20.75 & 100 & $15.1 \pm 10 \mathrm{l}-\mathrm{o}$ & 71 \\
& 41.5 & 200 & $12.1 \pm 1.6 \mathrm{~m}-\mathrm{o}$ & 67 \\
\hline & 1.562 & $10.3 \pm 1.0 \mathrm{no}$ & 56 \\
\hline
\end{tabular}


Continued from previous table

\begin{tabular}{ccclc}
\hline 5.18 & 6.25 & $15.9 \pm 2.2 \mathrm{k}-\mathrm{o}$ & 73 \\
10.37 & 12.5 & $15.6 \pm 1.9 \mathrm{k}-\mathrm{o}$ & 72 \\
20.75 & 25 & $14.5 \pm 2.1 \mathrm{l}-\mathrm{o}$ & 73 \\
41.5 & 50 & $8.6 \pm 1.1 \mathrm{o}$ & 81 \\
83 & 100 & $10.0 \pm 1.0 \mathrm{no}$ & 67 \\
\hline$n$-Butanol & 200 & $10.0 \pm 1.0 \mathrm{no}$ & 66 \\
\hline 166 & 1.562 & $33.1 \pm 2.2 \mathrm{f}-\mathrm{h}$ & 45 \\
& 1.29 & 3.125 & $32.4 \pm 1.7 \mathrm{f}-\mathrm{i}$ & 46 \\
& 5.59 & 6.25 & $25.9 \pm 1.8 \mathrm{~g}-\mathrm{l}$ & 55 \\
10.37 & 12.5 & $18.3 \pm 1.6 \mathrm{j}-\mathrm{o}$ & 68 \\
20.75 & 25 & $7.5 \pm 1.5 \mathrm{o}$ & 78 \\
41.5 & 50 & $10.0 \pm 1.0 \mathrm{no}$ & 67 \\
& 100 & $10.0 \pm 1.0 \mathrm{no}$ & 66 \\
\hline
\end{tabular}

Values with different letters in a column show significant difference $(\mathrm{P} \leq 0.05)$ as determined by Tukey's HSD Test.

\section{DISCUSSION}

In the present study, $P$. expansum was found as the causal agent of blue mold disease of grapes on both morphological and molecular bases. Blue mold decay is caused by many Penicillium species such as P. expansum, P. chrysogenum, P. rugulosum, P. polonicum, P. commune, P. italicum, P. digitatum, $P$. crustosum, $P$. solitum and $P$. verrucosum (Chen et al., 2017; Papoutsis et al., 2019; Duduk et al., 2021). Among these, P. expansum is the most virulent strain that produces toxins and causes blue mold decay of peach (Jiao et al., 2018), pear (Zhou et al., 2018), apple (Abdelhai et al., 2019), grapes (He et al., 2019) and quince (Luciano-Rosario et al., 2020).

As the pathogen has a wide host range, therefore, its management is very critical. For this, different fractions of $C$. murale leaf extract were used and the findings revealed that all the fractions had antifungal activities. Earlier, Naqvi et al. (2019) reported that different fractions of $C$. murale leaf extracts significantly reduced the growth of Fusarium oxysporum f. sp. lycopersici. Abdel-Wahhab et al. (2020) reported the presence of antioxidants, flavonoids and phenolic compounds with strong antimicrobial activities that might be responsible in reducing the growth of targeted fungal pathogen. $C$. murale extract also suppressed growth of Alternaria solani and Penicillium digitatum (Qasem and Abu-Blan, 1995) as well as Macrophomina phaseolina (Amin and Arshad, 2007). Antifungal activity of $C$. murale leaf extract could be due to presence of hexadecanoic acid, methyl ester; palmitic acid; phytol; $\beta$-sitosterol and methyl linolenate (Naqvi et al., 2019).
The present study concludes that $P$. expansum is the causal agent of blue mold disease of grapes in Pakistan. Being a post-harvest pathogen, it produces toxins and contaminates the food products during packing and processing. For its management, leaf extract of $C$. murale was used that significantly reduced the growth of targeted pathogen. Further studies regarding methods of application and mechanism of actions of the $C$. murale leaf extract, and identification of effective antifungal compounds are necessary for effective control measures of this pathogen.

\section{ACKNOWLEDGMENTS}

The authors wish to thank Professor Dr. Pierluigi Bonello, Molecular and Chemical Ecology of Trees, Department of Plant Pathology, Ohio State University, Columbus, USA, for providing lab facilities for molecular analysis. Authors also acknowledge the financial support by HEC Pakistan under IRSIP funding program.

\section{REFERENCES}

Abdel-Wahhab, M., H. Ahmed, A. El-Nekeety, S. AbdelAziem, H. Shara, M. Abdelaziz, M. Sallam and F. Mannaa. 2020. Chenopodium murale essential oil alleviates the genotoxicity and oxidative stress of silver nanoparticles in the rat kidney. Egyptian Journal of Chemistry, 63: 2631-46.

Abdelhai, M. H., H. E. Tahir, Q. Zhang, Q. Yang, J. Ahima, X. Zhang and H. Zhang. 2019. Effects of the combination of baobab (Adansonia digitata L.) and Sporidiobolus pararoseus Y16 on blue mold of 
apples caused by Penicillium expansum. Biological Control, 134: 87-94.

Akhtar, R., A. Javaid and M. Z. Qureshi. 2020. Bioactive constituents of shoot extracts of Sisymbrium irio L. against Fusarium oxysporum f. sp. cepae. Planta Daninha, 38: e020200961.

Al-Batsh, L. J. and J. R. Qasem. 2020. Phytotoxicity of wild plants extracts to redroot pigweed (Amaranthus retroflexus L.) and nettle-leaved goosefoot (Chenopodium murale L.). Pakistan Journal of Agricultural Sciences, 57: 1441-56.

Amin, M. and J. Arshad. 2007. Exploitation of allelopathic potential of Chenopodium species to control charcoal rot pathogen of sunflower. Pakistan Journal of Agricultural Research, 20: 130-36.

Banaras, S., A. Javaid and I. H. Khan. 2020. Potential antifungal constituents of Sonchus oleraceous against Macrophomina phaseolina. International Journal of Agriculture and Biology, 24: 1376-82.

Belmaghraoui, W., A. Manni, M. Harir, A. Filali-Maltouf, O. K. E. Fatni and S. E. Hajjaji. 2018. Phenolic compounds quantification, antioxidant and antibacterial activities of different parts of Urtica dioica and Chenopodium murale. Research Journal of Pharmacy and Technology, 11: 5490.

Chen, L. S., Y. J. Liu, S. W. Xu, Y. L. Chen, M. J. Chen and L. J. Zhou. 2017. First report of Penicillium polonicum causing blue mold on stored Polygonatum cyrtonema in China. Plant Disease, 101: 2149.

Cheng, X., T. Ma, P. Wang, Y. Liang, J. Zhang, A. Zhang, Q. Chen, W. Li, Q. Ge, X. Sun and Y. Fang. 2020. Foliar nitrogen application from veraison to preharvest improved flavonoids, fatty acids and aliphatic volatiles composition in grapes and wines. Food Research International, 137: 109566.

da Silva, L. E., C. Confortin and M. K. Swamy. 2020. Antibacterial and antifungal plant metabolites from the tropical medicinal plants. Advanced Structured Materials. Springer International Publishing. pp. 263-85.

Doyle, J. J. and J. L. Doyle. 1990. Isolation of plant DNA from fresh tissue. Focus, 12: 39-40.

Duduk, N., F. Bekčić, A. Žebeljan, N. Vučković and I. Vico. 2021. First report of blue mold caused by Penicillium crustosum on nectarine fruit in Serbia. Plant Disease, 105: 487.

FAOSTAT. 2020. FAO Production Year Book. Food and Agriculture Organization of the United Nations.
Rome, Italy.

Farhan, M. S., A. H. Khamees, O. H. Ahmed, T. A. A. and Y. S. Yaseen. 2019. GC/MS analysis of $n$-hexane and chloroform extracts of Chenopodium murale leaves in Iraq. Journal of Pharmaceutical Research International, 31: 1-6.

Ghuffar, S., G. Irshad, F. Naz, H. B. Rosli, S. Hyder, N. Mehmood, M. A. Zeshan, M. M. Raza, C. G. Mayer and M. L. Gleason. 2018. First report of two Penicillium spp. causing postharvest fruit rot of grapes in Pakistan. Plant Disease, 102: 1037-37.

González-Barreiro, C., R. Rial-Otero, B. Cancho-Grande and J. Simal-Gándara. 2014. Wine aroma compounds in grapes: A critical review. Critical Reviews in Food Science and Nutrition, 55: 20218.

He, C., Z. Zhang, B. Li, Y. Xu and S. Tian. 2019. Effect of natamycin on Botrytis cinerea and Penicillium expansum-Postharvest pathogens of grape berries and jujube fruit. Postharvest Biology and Technology, 151: 134-41.

Javaid, A., R. Munir, I. H. Khan and A. Shoaib. 2020. Control of the chickpea blight, Ascochyta rabiei, with the weed plant, Withania somnifera. Egyptian Journal of Biological Pest Control, 30: 1-8.

Jiao, W., X. Li, X. Wang, J. Cao and W. Jiang. 2018. Chlorogenic acid induces resistance against Penicillium expansum in peach fruit by activating the salicylic acid signaling pathway. Food Chemistry, 260: 274-82.

Kassemeyer, H.-H. 2017. Fungi of Grapes. Biology of Microorganisms on Grapes, in Must and in Wine. Springer International Publishing. pp. 103-32.

Khan, I. H. and A. Javaid. 2020. Comparative antifungal potential of stem extracts of four quinoa varieties against Macrophomina phaseolina. International Journal of Agriculture and Biology, 24: 441-46.

Luciano-Rosario, D., N. P. Keller and W. M. Jurick. 2020. Penicillium expansum: Biology, omics, and management tools for a global postharvest pathogen causing blue mould of pome fruit. Molecular Plant Pathology, 21: 1391-404.

Migicovsky, Z., J. Sawler, K. M. Gardner, M. K. Aradhya, B. H. Prins, H. R. Schwaninger, C. D. Bustamante, E. S. Buckler, G.-Y. Zhong, P. J. Brown and S. Myles. 2017. Patterns of genomic and phenomic diversity in wine and table grapes. Horticulture Research, 4: $1-11$. 
Morata, A., I. Loira, R. Vejarano, C. González, M. J. Callejo and J. A. Suárez-Lepe. 2017. Emerging preservation technologies in grapes for winemaking. Trends in Food Science \& Technology, 67: 36-43.

Naqvi, S. F., A. Javaid and M. Z. Qureshi. 2019. Evaluation of antifungal potential of leaf extract of Chenopodium murale against Fusarium oxysporum f. sp. lycopersici. Planta Daninha, 37: e019199050.

Naqvi, S. F., I. H. Khan and A. Javaid. 2020. Hexane soluble bioactive components of Chenopodium murale stem. Pakistan Journal of Weed Science Research, 26: 425-32.

Papoutsis, K., M. M. Mathioudakis, J. H. Hasperué and V. Ziogas. 2019. Non-chemical treatments for preventing the postharvest fungal rotting of citrus caused by Penicillium digitatum (green mold) and Penicillium italicum (blue mold). Trends in Food Science and Technology, 86: 479-91.

Qasem, J. R. and H. A. Abu-Blan. 1995. Antifungal activity of aqueous extracts from some common weed species. Annals of Applied Biology, 127: 215-19.

Samaras, A., P. Ntasiou, C. Myresiotis and G. Karaoglanidis. 2020. Multidrug resistance of Penicillium expansum to fungicides: whole transcriptome analysis of MDR strains reveals overexpression of efflux transporter genes. International Journal of Food Microbiology, 335:
108896.

Tragni, V., P. Cotugno, A. De Grassi, F. Massari, F. Di Ronzo, A. M. Aresta, C. Zambonin, S. M. Sanzani, A. Ippolito and C. L. Pierri. 2021. Targeting mitochondrial metabolite transporters in Penicillium expansum for reducing patulin production. Plant Physiology and Biochemistry, 158: 158-81.

Venkitasamy, C., L. Zhao, R. Zhang and Z. Pan. 2019. Grapes Integrated Processing Technologies for Food and Agricultural By-Products. Elsevier. pp. 133-63.

Vico, I., N. Duduk, M. Vasic and M. Nikolic. 2014. Identification of Penicillium expansum causing postharvest blue mold decay of apple fruit. Pesticidi i fitomedicina, 29: 257-66.

Wang, M., L. Zhao, X. Zhang, S. Dhanasekaran, M. H. Abdelhai, Q. Yang, Z. Jiang and H. Zhang. 2019. Study on biocontrol of postharvest decay of table grapes caused by Penicillium rubens and the possible resistance mechanisms by Yarrowia lipolytica. Biological Control, 130: 110-17.

Zhou, T., X. Wang, B. Ye, L. Shi, X. Bai and T. Lai. 2018. Effects of essential oil decanal on growth and transcriptome of the postharvest fungal pathogen Penicillium expansum. Postharvest Biology and Technology, 145: 203-12.

\section{CONFLICT OF INTEREST}

All the Authors declared no conflict of interest.

\section{AUTHORS CONTRIBUTIONS}

Iqra H. Khan did experimental work and contributed in manuscript writing. Arshad Javaid supervised the work, did statistical analysis and finalized the paper. Syeda F. Naqvi contributed in write up.

Publisher's note: EScience Press remains neutral with regard to jurisdictional claims in published maps and institutional affiliations.

Open Access This article is licensed under a Creative Commons Attribution 4.0 International License, which permits use, sharing, adaptation, distribution and reproduction in any medium or format, as long as you give appropriate credit to the original author(s) and the source, provide a link to the Creative Commons license and indicate if changes were made. The images or other third-party material in this article are included in the article's Creative Commons license, unless indicated otherwise in a credit line to the material. If material is not included in the article's Creative Commons license and your intended use is not permitted by statutory regulation or exceeds the permitted use, you will need to obtain permission directly from the copyright holder. To view a copy of this license, visit http://creativecommons.org/licenses/by/4.0/. 